\title{
Finnish High-Achieving Students' Perceptions of the Best Practices in Teaching
}

\author{
Mari Salmela ${ }^{1, *}$, Satu Uusiautti ${ }^{1} \&$ Kaarina Määttä ${ }^{1}$ \\ ${ }^{1}$ Faculty of Education, University of Lapland, Rovaniemi, Finland \\ *Corresponding author: Faculty of Education, University of Lapland, PO Box 122, 96101 \\ Rovaniemi, Finland. E-mail: msalmela@ulapland.fi
}

Received: March 16, 2015

Accepted: April 25, 2015

Published: May 4, 2015

doi:10.5296/ije.v7i2.7244

URL: http://dx.doi.org/10.5296/ije.v7i2.7244

\begin{abstract}
According to latest international student comparisons, Finnish students do relatively well at school. But how to maintain this level or even do better? This study focused on Finnish high-achieving students from the general upper secondary education. The purpose was to find out how these special students described their best teachers and teaching and, according to their narratives, what kind of teaching supported their strengths and study success the best. The study was based on the positive psychological theorization of good teaching in which teaching is understood as interaction that supports students' strengths. A narrative study approach was chosen and the sets of data included the Finnish straight-A graduates' $(\mathrm{N}=14)$ written and spoken narratives. The data were analyzed with narrative analyzing methods. The results introduced five core elements of teaching that support students' strengths and study success: (1) trust, (2) enthusiasm and zeal, (3) appreciation of achievements, (4) student-centeredness, and (5) dialogue. Based on the findings, opportunities to apply strength-based teaching are discussed.
\end{abstract}

Keywords: Strength-Based Teaching, Teaching, Positive Psychology, School, General Upper Secondary School, High-Achieving Student 


\section{Introduction}

From the learning results' point of view, Finland has a good and well-functioning education system. Finnish students have scored high in the Programme for International Student Assessment (PISA) for several years (Välijärvi, 2014). PISA is a survey taking place every three years among OECD countries evaluating 15-year-old students' skills in math, sciences, and literacy as well as to what extent students at the end of compulsory education, can apply their knowledge to real-life situations and be equipped for full participation in society (OECD, 2014). However, the latest PISA 2012 results (Kupari et al., 2013) are worrying in Finland as the Finnish students' scores have decreased. Students have reported that disturbances at school, problems in social relationships, and teachers' lack of interest in student well-being and support are the main reasons that hinder learning (Harinen \& Halme, 2012; e.g., see also Knesting \& Waldron, 2006; Shearman, 2003).

One of the most important future success factors is that how Finnish schools can make students be interested in studying, learning, and self-development (Sahlberg, 2014; San Antonio, 2008) and support their well-being and development into well-balanced members of society (e.g., Andolina, Jenkins, Zukin, \& Keeter, 2003; Zhao \& Kuh, 2004). School plays an increasingly important role in assisting students to develop cognitive, social, and emotional skills. Just as there are formulas and practices used to teach the skills of literacy and numeracy, there are formulas and practices that can be used to teach the skills for wellbeing, points out Waters (2011).

What kind of teaching would support learning and well-being the best in the current situation in Finland? In this study, the views of those Finnish students, who had performed after the compulsory 9-year-long basic education the 3-year syllabus of general upper secondary education and graduated with the best possible grades, on the best practices in teaching were studied. These students can be considered as the high-achievers in the school system and represent a clear minority of their age group (Matriculation Examination Board, 2012). The purpose of this study was to find out how these high-achieving students describe their teachers and their teaching. Thus, the interest was in what kind of teaching would support students' strengths and study success the best as described by these students.

The study leans on the theory of positive psychology. In this paradigm, studies often focus on people who can be seen as examples of positive development, behaviors, or adaptation in one or more areas of life (Magnusson \& Mahoney, 2003). In this study, high-achieving students' narratives are considered success stories revealing also the factors that have contributed to their success, such as the ways they were taught at school. The narratives can be useful when searching new viewpoints to how to improve and develop the Finnish education further. Furthermore, the study employed the idea of strength-based teaching as a specific background theory to interpret the findings.

\section{A Positive Psychological Perspective to Teaching}

To analyze teaching that would best support strengths and study success, the concept of 
strength-based teaching provides a useful theoretical viewpoint (Carman, 2005; Linkins, Niemiec, Gillham, \& Mayerson, 2014; O’Connell, 2006; see also Liesveld, Miller, \& Robinson, 2005; Yeager, Fisher, \& Shearon, 2011). Those teachers who embrace a strength-based perspective hold the belief that all students have strengths, resources and the ability to recover from adversity. This perspective replaces the emphasis on problems, vulnerabilities, and deficits. It identifies and reveals a student's internal strengths and resources as they emerge in response to specific life challenges. It is important to understand the strength-based teaching is not denying that student do experience problems and challenges and that these issues do need to be addressed. But, when a problem emerges, it will addressed with positive expectations and opportunities for change (Linkins et al., 2014; O'Connell, 2006). Next, we will define and describe strength-based teaching in detail.

Strength-based teaching turns attention from students' weaknesses to their strengths (Carman, 2005). Curricula with their objectives, contents, and evaluations can lead to a situation that teachers see primarily what students cannot do, what they should know, and how they should be like in the future (Viskari, 2003). This kind of viewpoint ties teaching around students' weaknesses and deficiencies. Whereas in strength-based teaching, teachers try to perceive students as they are. Each student has his or her unique strengths and opportunities that can flourish in favorable conditions (see also Seligman, 2011). Instead of pointing out weaknesses, strength-based teaching focuses on discovering and cherishing these strengths (Linkins et al., 2014). Teaching is based on the idea according to which focusing on weaknesses causes fear and uncertainty as well as mistrust in one's abilities; this can reflect negatively in study motivation and the whole learning process (Liesveld et al., 2005). Consequently, recognition and using of strengths arouse positive emotions and increase motivation in students (Carman, 2005).

How are strengths and weaknesses defined in this ideology? In positive psychology research, the researchers categorize human strengths in many ways. These categorizations differ from each other by their definitions of strengths and terminology (Quinlan, Swain, \& Vella-Brodrick, 2012). These viewpoints share the understanding of strength as a positive feature that describes a person at his or her most genuine (Linley, Willars, \& Biswas-Diener, 2010; Rath, 2007; Seligman, 2011). Strengths are manifested in people's thoughts, emotions, and action, and are adjustable (Yeager et al., 2011). Using one's strengths provides pleasure and satisfaction, allowing the best possible action, development, and performances to occur. Actually, these two dimensions together, energy and performance, distinguish strengths from learned behaviors, which refers to behaviors one can perform well, but that do not provide the sense of fulfillment or power but are merely de-energizing (Linley et al., 2010). Weaknesses, on the other hand, are something that a person does not do well or perform well or find pleasure in, but merely, weaknesses misspend energy and can be harmful to self-image (Carman, 2005; Linley et al., 2010). Therefore, a feature to be defined as someone's strength, has to include the dimensions of energy and performance (Linley et al., 2010). Human strength research shares an understanding of the beneficial consequences for well-being, happiness, and contentment when utilizing one's personal human strengths. Likewise, researchers connect them with engagement to and achievement of goals as well as with 
efficient and quality action (see Quinlan et al., 2012; Wood, Linley, Maltby, Kashdan, \& Hurling, 2011).

The strength-based teaching is based on the trust between a teacher and student; it is considered the prerequisite of positive development (Carman, 2005). Trust is a by-product of caring and affection expressed by the teacher (Liesveld et al., 2005; van Manen, 2002; Yeager et al. 2011). Trust creates hope and functions as an emotional glue supporting students at times of trouble and adversities, helping them reach their goals, and strengthening their belief in themselves and their abilities (Carman, 2005). Määttä and Uusiautti (2012b) refer to pedagogical tact, which emerges in the teacher's ability to be loving and present and an expert authority simultaneously. Pedagogical tact is also manifested as the teacher's trust in students' abilities and as a positive obligation to support students (see van Manen, 2002). In strength-based teaching, the emphasis of teaching turns from outer control and teacher-led teaching into student-centered learning encouraging students be responsible for their learning (Carman, 2005) and increasing their opportunities by supporting their strengths (Peavy, 1996).

The orientation to positive has often been criticized for not acknowledging negativity, which is a natural part of life (Held, 2004). However, positive psychology or strength-based teaching should not be mixed with overly positive, uncritical thinking - quite the contrary. In this study, we are aware of that Finnish students' self-esteem, motivation, or interaction with teachers will not improve by repeating positive words, using supportive language. Here, strength-based teaching is considered a philosophical foundation and related practical actions that can mold the teacher's and the student's perceptions of teaching, learning, and the student himself of herself (Lopez \& Louis, 2009). Strength-based teaching leads the analysis of teaching that can, in addition to learning of cognitive skills and abilities, create such practices and conditions for learning that enable wide use of cognitive skills and abilities.

\section{Method}

The purpose of this study is to describe teaching and teachers that support students' strengths and study success the best from high-achieving students' perspective. The following research questions were set for this study:

(1) How do straight-A graduates describe their best teachers and their teaching?

(2) What kind of teaching supported the best the straight-A graduates' strengths and study success?

The ultimate purpose is to analyze both positive and negative experiences of teaching, and discover possible ways to improve teaching based on the participants' narratives. Straight-A graduates from general upper secondary education in Finland were selected as participants to this research. The selection was based on their performance in the Matriculation Examination which ends the general upper secondary education and is a nation-wide examination. The exam is held twice a year and at the same time in all Finnish general upper secondary 
education schools. The Matriculation Examination includes at least four separate tests in the Finnish language and literature and in three optional school subjects (Finnish National Board of Education, 2003). Students can also take additional tests in subjects they prefer (Law on General Upper Secondary Education 1998/629). On average, Finnish students take tests in roughly five subjects (Matriculation Examination Board, 2012).

The Matriculation Examination is scored with the following grades (from highest to lowest): laudatur (L), eximia cum laude approbatur (E), magna cum laude approbatur (M), cum laude approbatur (C), lubenter approbatur (B), approbatur (A), and improbatur (I), a failing grade. The relative proportion of each grade among graduates is same every year: L is give to $5 \%$ of students, E to $15 \%, \mathrm{M}$ to $20 \%, \mathrm{C}$ to $24 \%$, B to $20 \%$, A to $11 \%$, and I to $5 \%$. This means that the best $5 \%$ of students gets laudatur (L) (Matriculation Examination Board, 2012). Because of the relational scoring system, the grading scale is not directly comparable to, for example, the American four point letter grade system (from F to A+). However, the English word "straight-A" graduates felicitously refers to graduates who complete their education with laudatur grades.

Every year, about 30,000 students graduate from general upper secondary education, and 40 to 104 of them $(0.13 \%-0.35 \%)$ score a laudatur in six or more subjects yearly (Matriculation Examination Board, 2012): there are only about 30-70 graduates per year having six laudatur grades, only 2-11 graduates per year having eight laudatur grades, and approximately only one graduate per year having more than eight laudatur grades. In this study, the concept of a straight-A graduate refers to a student who has gotten at least six laudatur grades from the matriculation examination.

The data collection started in summer 2012 by mailing 19 straight-A graduates a request to write an essay. The participants had to fulfill the following selection criteria: they must have graduated from general upper secondary education schools from 2010 to 2012 with at least six laudatur grades. Fourteen $(\mathrm{N}=14)$ graduates replied to the request by sending their written narratives. Eleven of them were women, three were men. The low number of men can be partly explained because women tend to perform better than men in the examination, and most of the Finnish general upper secondary education students are women $(60 \%)$ (Matriculation Examination Board, 2012). Due to the low number of the straight-A graduates, their anonymity is protected as carefully as possible. This means that their graduation year or schools cannot be revealed, nor is it possible to tell how many laudatur grades each of them had in the Matriculation Examination. To sum, they all had at least six laudatur grades, and graduated from municipally-organized general upper secondary education across Finland in 2010-2012.

The participants were given directions about how to write essays. They were asked to write freely about all those events, and experiences they considered important during their school paths. In addition, they were asked to describe the role of school and teachers in their school paths starting from elementary education. The purpose was to avoid questions that would have guided or limited the participants' narratives too much. The narratives were rich, profound reports from two to 15 sheets of length. 
These data were complemented by interviews in 2013. The researcher sent the interview request to all 14 participants who had participated in the study with their written narratives. Half of them ( $\mathrm{N}=7$; 4 women, 3 men) replied and the researcher interviewed them personally. The written narratives functioned as the foundation of the interviews. The researcher could refer to the narratives and ask questions inviting the participant to tell more about an interesting part of the narrative. In addition, the participants were asked to describe lessons they had found pleasant or unpleasant and the teachers, teaching, and atmosphere of these lessons. The interview method was reminiscent of an episodic interview, which is a combination of narrative and themed interviewing methods (Bates, 2004). Each interview lasted about an hour.

The research applied the narrative approach that follows the principles of social-constructionism (Burr, 1995). The approach has four tasks in this study. Firstly, the data are in the form of narratives. The straight-A graduates' written and spoken narratives included emotions, thoughts, and experiences as well as descriptions of events from their school paths. Their narratives are seen as a way to understand one's own and others' actions, to organize events as a meaningful entity, and to understand consequences of action (Bruner, 1986; Holstein \& Gubrium, 2012; Polkinghorne, 1995). Secondly, narrative refers to the process and nature of knowledge as a manifestation of constructivist knowing (Bruner, 1990; Polkinghorne, 1988). People construct their understanding and identities constantly through narratives. Narratives manifest meanings that individuals have created about their lives and themselves. Knowing is, therefore, seen to be connected with time, place, and social context.

Thirdly, this study employed narrative data analyzing methods, following the ideas of McAdams's (2012) the context of discovery and differences analysis (Alasuutari, 1995), as the purpose was to reconstruct themes from singular statements about teachers and teaching as well as differences between them. The context of discovery analysis resembles Riessman's (2008) thematic analysis that is interested in the contents of narratives, in other words, what the straight-A graduates tell about their best teachers and their action (Chase, 2008; Holstein \& Gubrium, 2012; Riessman, 2008). It also involved features of categorical-content analysis (Lieblich, Tuval-Mashiach, \& Zilber, 1998), as the purpose was to reduce, group, and find categories in the data. The analysis of differences (Alasuutari, 1995) focused on discovering differences in statements in the data. The purpose was to analyze how the best teachers and teaching practices were revealed by describing the actions of disagreeable teaching. The analysis in this study thus combines the themes created by the context of discovery and analysis of differences within the data.

Fourthly, the narrative approach is a means to evaluate reliability of the study. The straight-A graduates' narratives are context-bound and influenced by interaction. It means that narratives are told differently to different people in different situations (Chase, 2008; Denzin \& Lincoln, 2005). Thus, narratives can be seen as the mutual product produced by the straight-A graduates and the researcher through their interaction. The interpretations made by researchers are narratives as well. The authors of this article present ideas of how to develop teaching to support students' strengths and study success. Therefore, the findings and conclusions are not claims about the reality as such but a part of the reality under 
investigation (Alasuutari, 1995; 1996; Chase, 2008; Holstein \& Gubrium, 2012). The results of analysis can only state that certain themes and different dimensions emerged from the data that the readers can evaluate and contemplate against the researchers' choices and solutions as described in the article.

\section{Results}

The analysis found five themes that emerged from the straight-A graduates' narratives and that describe teaching that support students' strengths and study success. The elements of (1) trust, (2) enthusiasm and zeal, (3) appreciation of achievements, (4) student-centeredness, and (5) dialogue will be introduced next.

(1) Trust

The straight-A graduates' $(\mathrm{N}=13)$ best experiences were related to teachers with whom they had had personal relationships. This teacher-student relationship was described by teachers' abilities to show the directions and caring by requiring hard work from students but simultaneously nurturing their learning processes. In practice, this was manifested by knowing students by name, asking how they are doing, showing interest in their needs and points of interest. In addition, the straight-A graduates had found it important for their study motivation that teachers treated students fairly and evenly.

On the other hand, teachers' unfairness had influenced negatively on motivation and created distance between teachers and students because it tore apart mutual respect and trust. The straight-A graduates described in their narratives how difficult it was understand why they had to listen to a teacher and learn about the subject he or she was teaching if the teacher did not genuinely care for students' and their feelings. One straight-A graduate described this by stating how an unfair teacher could kill the interest in the school subject in a snap (Graduate10, written narrative, July 2012). The following data excerpts illustrate how trust in the teacher-student relationship was described in the data:

"My favorite teachers have been difficult in others' opinion: strict and demanding. I have the best memories of teachers with whom I had a personal relationship, who seemed like they knew me. I have always found it important that I can respect my teacher. - - If a teacher acts unfairly, my respect has disappeared at once and for all. One of my worst memories is from the handicraft lesson at elementary school, when the teacher showed my work to the class and stated that it was 'an exceptionally good example of an exceptionally bad example.." (Graduate3, written narrative, July 2012)

"A good teacher also demands work from students, is fair and just, and does not accept tardiness or disturbance: nothing is more frustrating than when you have toiled to finish some task required in the course, and still another student who has not finished the task gets the same grade. After that, you will definitely not want to invest in studying at that teacher's courses." (Graduate9, written narrative, July 2012)

The straight-A graduates' narratives illustrate the power of positive relationships (Carman, 
2005); positive change occurs in the context of authentic relationships (O'Connell, 2006). Students need to know that they can have supportive and caring relationships with school staff-relationships that reflect trust, respect, and non-judgment. Teachers can show their support and caring by listening and accepting emotions that students feel and express as well as by expressing friendship, companionship, and respect. It is important that teachers refrain from judging and understand that students try to do their best based on what they have learned. Positive relationships are constructs of hope and optimism in students.

\section{(2) Enthusiasm and zeal}

The straight-A graduates $(\mathrm{N}=10)$ described how teachers who hurled themselves in their work, felt genuine joy of work, and were curious and enthusiastic transmitted their positive attitudes to students making the school subject seem more interesting. Therefore, the zeal and enthusiasm expressed by teachers reflected positively to students' work as well. This was considered especially important when the school subject did not interest the straight-A graduates themselves. On the other hand, their narratives showed that the teacher's training, experience, and substance knowledge lose quickly their meaning without any passion toward or interest in the subject:

"How could students be motivated to learn if the teacher seems to think that [the subject the teacher teaches] is not useful?" (Graduate9, written narrative, July 2012)

The following excerpt exemplify how the teacher's substance knowledge and expertise, education and experience, need some enthusiasm alongside in other to reach students better:

"The teacher talks about trips in France and Russia. The teacher was really enthusiastic about the school subject, it was very important. Of course, if the teacher enjoys his or her work, it shows to students. You can sense it. It was like, perhaps you studied harder those subjects at home and listened during lessons. - - Then again, there were subjects that you were not much interested in, such as the first language [Finnish]. I have not been much of a reader ever but there the atmosphere was so oriented toward the matriculation examination and the teacher just tried to hammer those things into our heads. I do not know if the teacher was doing literature at all because the teacher lacked the passion totally. The teacher tried to do those basic things, according to the curriculum, but was not able to inspire us to study." (Graduate1, individual interview, June 2013)

"Some teachers were like pearls, for example our biology teacher who loved nature and natural phenomena and showed us pictures of fall colors in the North and northern lights. Although I was not really interested in biology, the teacher made it come alive from the pages of books. During this teacher's lessons, you did not dare not to do your best, because it would have been a downright insult toward the teacher." (Graduate3, written narrative, July 2012).

The straight-A graduates' narratives showed that the teacher is not just an instructor for academic skills, but also a positive role model who, through his or her own action and stories, exhibits love for knowledge and wisdom and invites the students to find this love with his or her enthusiastic, curious attitude (Liesveld et al., 2005). The teacher's education, substance knowledge, and experience have traditionally been considered the cores of teacher's work 
(see Liesveld et al., 2005). The idea is that teachers have to be experts of their subjects both theoretically and practically in order to be able to show the core areas to be learned and mastered. However, it seems that students do not respond to seniority or post-graduate degrees but merely to teachers who have passion for their work (Liesveld et al., 2005).

\section{(3) Appreciation of achievements}

The straight-A graduates $(\mathrm{N}=9)$ highlighted also the importance of demands, obligations, and goals because they made the students stretch their skills. Likewise, the participants described how teachers' low expectations had stopped the development and did not help the student surpass their own abilities and develop their skills and knowledge.

"I always liked it a lot if the teacher was demanding, did not let up on, was kind of strict but simultaneously really fair and nice. - - I hate those teachers how are too fussy, because I lose interested if there is no challenge. There should be something what we are aiming at. If there is no goals, it will not work. If there is nothing that would make you surpass yourself, why would you do it - if no one makes you enthusiastic about it or challenge your thinking?" (Graduate2, individual interview, July 2013)

The straight-A graduates hoped for more "inspiring and boosting" teaching (Graduate14, individual interview, July 2013). They considered it important that the teacher sees the students' strengths also in times of failures and helps them to recognize what they are good at. The straight-A graduates described how especially in adversities teachers' positive expectations on students' skills and strengths helped them to appreciate their skills and let go harmful beliefs of their abilities.

"Math teachers from my general upper secondary school are concrete examples. It was the second course of math that I studied according to the advanced syllabus, and I had a D after a second try. After that, my self-esteem as a math student altered roughly. - - Math studies were shadowed by my negative perception of myself as a math learner which probably partly inhibited me really trying to learn and be interested in math. However, my math teachers were not influenced by my varying study success in math and low subject-related self-esteem as their attitude to, interest and trust in my talents did not seem to be dependent on my grades. Instead, they were always willing to help me with my problems and cast trust in my skills." (Graduate5, written narrative, July 2012)

According to Yeager et al. (2011), students whose faith in their talents is shaking benefit the most from teachers' concrete examples that illustrate those times that they have succeeded and showed perseverance. Teachers can challenge students to do their best by supporting their trust in their skills and abilities (Carman, 2005). It means that the teacher does not set too high expectations but the right expectations for each student. Rather than inspiring students to greatness or encouraging them to achieve, those impossible expectations doom students to failure and can erode their self-esteem. In addition, they do not help students stretch or exceed their present abilities by developing new ones (Liesveld et al., 2005). Moreover, teaching should acknowledge the successes by giving positive feedback, not matter how small the successes are (Linkins et al., 2014). Recognition is a powerful motivator, more so 
when given publicly, and especially when it is presented for an achievement of which the student is truly proud (Liesveld et al., 2005).

\section{(4) Student-centeredness}

The straight-A graduates $(\mathrm{N}=9)$ described student-centeredness in teaching in various ways. Lessons that included participatory tasks and had varied contents provided moments of inspiration and joy at school. The participants reported how teachers could challenge students to create contents to lessons by giving them project tasks that allowed them to combine widely knowledge and skills and to create something new, such as written presentations, radio plays, or dramas. The straight-A graduates emphasized student-centeredness also by criticizing teacher-led lessons that following inflexible structure and contents: students listened to teachers, copied sentences from the blackboard, and checked homework by looking for right answers and correcting wrong ones. These lessons appeared frustrating and decreased their motivation regardless of students' study success.

"We had really nice tasks that made us find out about a geographical area, both about its geological features influencing there and societal issues. And that were so extensive that took months to finish before they could be returned. They were really nice. Whereas this usual homework that we checked in the following day did not inspire me much. Especially because at the general upper secondary school, lessons were mostly about checking homework leaving the actual learning of contents or teaching in the backseat." (Graduate13, individual interview, June 2013)

The straight-A graduates' narratives reveal that teachers should not teach all classes or students in the same way but employ students' backgrounds and stories so that they value what is important to the students (Carman, 2005). This does not mean that teachers should entertain students, but the idea of employing students' points of interests is to draw their attention to the contents and arouse their interest, to make learning easier as well. By creating flexible structures and contents, the teacher encourages students to participate and take responsibility over their learning (Liesveld et al., 2005). Students develop a sense of pride and acceptance when they are encouraged to participate in ways that reflect their interests and strengths (O'Connell, 2006). The finding suggests that the organization of teaching should be decentralized by moving toward student-centeredness from teacher-directedness (see also Carman, 2005).

\section{(5) Dialogue}

Half of the straight-A graduates $(\mathrm{N}=7)$ described how teachers and students had much important to give in the teaching and learning processes. Both parties of processes have the opportunity be active, creative, and to indulge in intelligent thinking and conversation. The straight-A graduates appreciated dialogue as a teaching method because it enables reciprocal flow of information.

The opposite of dialogue was described in the participants' narratives as well. They were lessons in which the atmosphere stated "I teach and you are the students, which is nothing where students and the teacher are equal as human beings" (Graduate1, individual interview, 
June 2013). The difference between authoritarian and dialogic conversations was illustrated also with a wish for a more mature atmosphere in the general upper secondary education instead of basic-education-like teaching. According to Graduate6 (written narrative, July 2012), sometimes teachers seemed to forget how people should discuss at the general upper secondary school. Teachers could make remarks about students' hats or inquire after absence notes instead of inviting students to mutual conversation about how to behave in classroom situations and how to maintain peace to learn.

According to Liesveld et al. (2005), a good teacher encourages students to participate in teaching thus helping them be responsible for their studies. Teachers should hold the belief students need to be allowed to express their opinions and imagination, make choices, problem solve, work with and help others because this promotes students' opportunities for ownership (O’Connell, 2006).

\section{Conclusions}

Based on the results of this study, it can be concluded that the straight-A graduates' narratives highlighted five core elements of teaching that support students' strengths and study success. They manifest those circumstances and features that, when cherished and maintained by teachers, can support students to find their intrinsic motivation to learn and belief in their strengths and skills. Simultaneously, they provide ideas about how to promote teaching in Finnish schools to better support strengths and study success.

\section{Core Element 1: Trust}

The first of the core elements of teaching is trust in students' abilities. It is very close to the idea of caring and nurturing (Noddings, 2005). The trust manifested by the teacher is more than compliments, fussiness, or paying attention to students. Merely, it means acceptance and genuine interest in students as individuals. The straight-A graduates' narratives showed how each student, even those who are high-achievers, need the sense of becoming unconditionally accepted, understood, heard, and appreciated as himself or herself (see also Liesveld et al., 2005; van Manen, 2002; Yeager et al. 2011). This kind of trust is a significant construct and of social action and foundation for identity construction leading to mutual respect at its best (Noddings, 2005; see Heikkinen \& Huttunen, 2002). Trust is also a prerequisite of a student's positive development. Trust creates hope and functions as emotional glue that supports students at times of adversities and trouble, and helps them achieve their goals and strengthen their belief in themselves and their abilities (Carman, 2005). The most valuable gift that a teacher can give is the gift of trust and presence (Carman, 2005; Peavy, 1996).

\section{Core Element 2: Enthusiasm and zeal}

The second core element of teaching is related to the teacher's attitude toward his or her work. The straight-A graduates' narratives showed how teachers should not only be experts of the substance, but also be ready to indulge in teaching and show their passion and interest in the subject. This core element illustrates bricoleur activity (Lévi-Strauss, 1966). Teachers can 
create solutions to students' challenges and problems by using their education and experience as well as by indulging and trusting their instincts. Teachers who approach students and learning processes with a playful attitude open doors for new ideas that can be studied together with students. Teaching collects various options, searches, and finds out students' strengths and leans on students' shared narratives (Lévi-Strauss, 1966). Thus, new information is always welcome and actively used by teachers and students (Peavy \& Li, 2003).

\section{Core Element 3: Appreciation of achievements}

The third core element of teaching includes positive feedback and encouragement. The straight-A graduates emphasized that in addition to appreciation of achievements and outcomes, teachers should actively provide positive feedback to students. This need refers to the dialectics of recognition (Heikkinen \& Huttunen, 2002) and individuals' opportunity to choose (Peavy, 2000; Peavy \& Li, 2003). Students' growth and development are more than the development of intellectual abilities and skills. Teaching should also help students recognize their strengths and achievements and appreciate themselves and their action. Positive expectations and encouragement help students learn their special identities and construct positive images of themselves (Heikkinen \& Huttunen, 2002). Thus they find more opportunities to choose from goals that are the most suitable to themselves (Peavy, 2000; Peavy \& Li, 2003). In other words, thanking and appreciation can strengthen those knowledge, skills, talents, and abilities that students need to reach their desired goals regardless of their study success. Teachers should recognize each student's personal moments of success and provide positive feedback and public recognition whenever possible.

\section{Core Element 4: Student-centeredness}

The fourth core element of teaching is student-centeredness. It means that students' needs, interests, and experiences are employed in teaching. It is also a question about finding a common ground (Peavy, 2000; Peavy \& Li, 2003) instead of entertaining students. Teachers should be willing to understand something about which things matter to students and how they lead their lives. The purpose is that the teacher and students would find similar points of interest to which they could lean on during the learning process. Teaching can be started with issues that relate to the students' current life situations and interests. This would function as an example of the adaptation of constructivist ignorance and how teachers can give students a chance to teach the teacher about issues important in their lives (Peavy, 2000; Peavy \& Li, 2003; see Noddings, 2005).

\section{Core Element 5: Dialogue}

The fifth core element focuses on the encounter of two people, a teacher and student, and conversation between them. The straight-A graduates' narratives illustrated the "human face", as described by Peavy (Peavy, 2000). Human face in dialogue implies that teachers try to avoid representing them as better than students, official guides and advisors who know more or what is best for students. This does not deny the differences between teachers' and students' experiences and social statuses. Instead, dialogue shows respect for each other as 
unique and valuable human beings who have important experiences to tell and share. Human-face dialogue also means that both parties are open to various perspectives and willing to create collaboration that enables both to contribute to the dialogue (Peavy, 2000; Peavy \& Li, 2003).

\section{Discussion}

This study attempted to grasp a very topical theme of maintaining and enhancing students' school success. The study highlighted five elements that appeared to support students' strengths and study success the best according to those students that have succeeded well in their studies. These conclusions can help focusing teaching on elements that could benefit students considerably when the aim is to increase students' motivation and belief in their strengths, and most importantly, strengthen their self-esteem, self-confidence, and social relationships at school. They are the core conditions for succeeding in life. The findings are easily adaptable to various levels of education all the way from basic education to secondary education thus benefitting all students regardless of their success, abilities, social background, or place. Both low-achievers and high-achievers at school need teachers who express trust, appreciation, and caring toward students by their action and enthusiasm. These features help students to tolerate and manage burdensome studies, to recognize strengths in themselves to balance the performance-related demands, and to appreciate themselves and their achievements as they are (Salmela \& Määttä, 2015; Salmela \& Uusiautti, 2013; 2015; see also Peterson, Duncan, \& Canady, 2009.)

There are also interventions, such as the Penn Resiliency Programme (PRP) (Seligman, Ernst, Gillham, Reivich, \& Linkins, 2009) and "You Can Do It!" (YCDI) (Bernard \& Walton, 2011), that have been designed to foster students' academic performance and well-being by following a positive psychological perspective to strength-based teaching (Waters, 2011). These programs teach cognitive reframing, assertiveness, and creative brainstorming and give lessons in resilience, persistence and getting along. Interventions show that skills and mindsets that promote positive emotions, positive relationship and character strengths also promote learning and academic performance as well as well-being at school (Leskisenoja \& Uusiautti, 2015). In addition, the straight-A graduates' narratives showed that the core elements of teaching that support students' strengths and study success do not demand any major new additions to teaching, but they can be adopted as a part of curriculum-directed teaching. If anything, the core elements are attitudes and methods applicable in the everyday life at school and manifested by teachers' way of perceiving teaching, learning, and students. The elements resemble the need to create practices that support students' motivation, learning, and study success as well as well-being and positive self-image.

In strength-based teaching, language usage is based on the constructivist perspective defining language as an important means of constructing reality (Bruner, 1990). The language used in strength-based teaching highlights opportunities, hope, and solutions instead of students' problems, hopelessness, and flaws (O’Connell, 2006; see also Peavy, 1996). In practice, positive language emerges, for example, the teacher saying "It seems that you have tried to 
solve the task differently. Let us see how it turned out" instead of scolding "Did you not hear what I told and taught in the previous lesson?" A teacher can also welcome a student who is constantly late by saying "Nice to see you here" instead of reproaching before finding out the real reason behind tardiness, which can be, as Äärelä's (2012) study showed, due to other than student-bound factors such as parents' alcoholism or inability to take care of their child. In this data, the language element was not strongly emphasized by the straight-A graduates, even though it is a recognized part of strength-based teaching. Therefore, this study cannot describe teaching from the perspective of positive language usage. Indeed, the future studies could focus especially on how teachers talk to and with students to support their strengths and study success.

Students who are willing to study and interested in learning, such as straight-A graduates are (see Salmela \& Määttä, 2015; Salmela \& Uusiautti, 2013; 2015), evaluate often positively their learning environments (Pulkka \& Niemivirta, 2013). These students as high-achievers are significantly above the average students' grades. Given this fact, it is reasonable to ask to which extent the selection of these participants gives biased results and conclusions about teaching that would support students' strengths and study success the best. On the other hand, much can be learned from their experiences and perceptions that can benefit various learners. In addition, it is interesting to learn that the core elements highlighted by the straight-A graduates were similar to those mentioned by Finnish young (17-21 years old) prisoners (Äärelä, 2012; see also Äärelä, Uusiautti, \& Määttä, 2014), who can be seen as the other extreme of the achievement spectrum. Äärelä's study reported that the young prisoners' ideas of how to develop education included caring, acceptance, and holistic attention. They wished teachers would provide positive feedback, be more human and mature, and show caring and take care of solidarity (see also Cassidy \& Bates, 2005). Furthermore, teachers' attitude to their own work was also pointed out in the young prisoners' narratives (Äärelä, 2012).

It is important to understand that although this study focused on analyzing teachers' action, teaching that support students' strengths and study success covers three different levels that are the teacher, classroom, and school levels (O'Connell, 2006). The challenge for school administrators and teachers is to perceive opportunities to this kind of teaching, to find ways to enact teaching that support students' strengths and study success, and to do this in an era of competing expectations and pressures. According to Cassidy and Bates (2005), how to balance these demands, in various educational contexts, is a topic that merits further study. Indeed, based on the study at hand, it would be interesting to analyze how the core elements of teaching that supports students' strengths and study success are manifested in students' mutual relationships and interaction, or how they are paid attention to in school administration and collaboration with partners. Namely, fostering the development of the whole student needs to involve the school, family, and community as well and therefore, it is crucial that the strength-based principles are followed across the different levels (O'Connel, 2006; see also Waters, 2011). The conclusion is that students' strengths and study success should not be viewed separate from the context. Nor is the purpose of this study to argue that Finnish students' motivation, skills, and well-being could be improved just by analyzing teaching and teachers' work. Curricula and learning goals, contents, and evaluations (see 
Määttä \& Uusiautti, 2012a), the larger educational systems and collaborations (Waters, 2011), as well as other social and cultural factors, such as families' social status and parents' education (see Hickman, Bartholomew, Mathwig, \& Heinrich, 2008; Norberg-Schonfeldt, 2008; Warburton, Bugarin, \& Nuñez, 2001) have their own role in directing students' expertise, well-being, and attitude to school and learning.

\section{Acknowledgement}

The research is financed by the Finnish Cultural Foundation.

\section{References}

Äärelä, T. (2012). “Aika palijon vaikuttaa minkälainen ilime opettajalla on naamalla." Nuoret vangit kertovat peruskouluajoistaan ["It means quite a lot what kind of look a teacher has" Young prisoners talking about their experiences at a comprehensive school]. (PhD Diss., University of Lapland, Rovaniemi.)

Äärelä, T., Uusiautti, S., \& Määttä, K. (2014). "The teacher should not just boss around all the time". Good teacherhood in the light of young prisoners' experiences. Problems of Education in the 21st Century, 60(60), 10-22.

Alasuutari, P. (1995). Researching culture: Qualitative method and cultural studies. London: Sage.

Alasuutari, P. (1996). Theorizing in qualitative research: A cultural studies perspective. Qualitative Inquiry, 2(4), 371-384. http://dx.doi.org/10.1177/107780049600200401

Andolina, M. W., Jenkins, K., Zukin, C., \& Keeter, S. (2003). Habits from home, lessons from school: influences on youth civic engagement. Political Science \& Politics, 36(2), 275-280. http://dx.doi.org/10.1017/S104909650300221X

Bates, J. A. (2004). Use of narrative interviewing in everyday information behavior research. Library \& Information Science Research, 26, 15-28. http://dx.doi.org/10.1016/j.lisr.2003.11.003

Bernard, M. E., \& Walton, K. (2011). The effect of You Can Do It! Education in six schools on student perceptions of wellbeing, teaching, learning and relationships. Journal of Student Wellbeing, 5(1), 22-37.

Bruner, J. (1986). Actual minds, possible worlds. Cambridge: Harvard UP.

Bruner, J. (1990). Acts of meaning. Cambridge: Cambridge University Press.

Burr, V. (1995). An introduction to social constructionism. London: Routledge.

Carman, T. J. (2005). Strength-based teaching: the affective teacher, No Child Left Behind. Oxford: Scarecrow Education. 
Cassidy, W., \& Bates, A. (2005). "Drop-outs" and "push-outs": Finding hope at a school that actualizes the ethic of care. American Journal of Education, 112, 66-102.

Chase, S. (2008). Narrative inquiry: Multiple lenses, approaches, voices. In N. K. Denzin \& Y. S. Lincoln. (Eds.), Collecting and interpreting qualitative materials (pp. 57-94) (3rd ed.) London: Sage.

Denzin, N. K., \& Lincoln, Y. S. (2005). Introduction: The discipline and practice of qualitative research. In N. K. Denzin \& Y. S. Lincoln (Eds.), The Sage handbook of qualitative research (pp.1-32) (3rd ed.). Thousand Oaks, CA: Sage.

Finnish National Board of Education. (2003). Lukion opetussuunnitelman perusteet 2003 [The core curriculum for general upper secondary education 2003]. Helsinki: Finnish National Board of Education.

Harinen, P., \& Halme, J. (2012). Hyvä, paha koulu. Kouluhyvinvointia hakemassa [Good, bad school. Looking for well-being at school]. Helsinki: Unicef Finland.

Heikkinen, H. L. T., \& Huttunen, R. (2002). "Huomaa minut, arvosta minua!" Opetus tunnustuksen dialektiikkana ["Notice me, appreciate me!" Teaching as the dialectics of appreciation]. In P. Sallila, \& A. Malinen (Eds.), Opettajuus muutoksessa [Teacherhood in change] (pp. 278-294). Helsinki: Kansanvalistusseura ja Aikuiskasvatuksen Tutkimusseura.

Held, B. S. (2004). The negative side of positive psychology. Journal of Humanistic Psychology, 44(1), 9-46. http://dx.doi.org/10.1177/0022167803259645

Hickman, G. P., Bartholomew, M., Mathwig, J., \& Heinrich, R. S. (2008). Differential developmental pathways of high school dropouts and graduates. The Journal of Educational Research, 102(1), 3-14. http://dx.doi.org/10.3200/JOER.102.1.3-14

Holstein, J. A., \& Gubrium, J. F. (2012). Varieties of narrative analysis. London: Sage.

Knesting, K., \& Waldron, N. (2006). Willing to play the game: How at-risk students persist in school. Psychology in the Schools, 43(5), 599-611. http://dx.doi.org/10.1002/pits.20174

Kupari, P., Välijärvi, J., Andersson, L., Arffman, I., Nissinen, K., Puhakka, E., \& Vettenranta, J. (2013). PISA12. Ensituloksia [PISA12. Initial results]. Helsinki: Ministry of Education and Culture.

Law on General Upper Secondary Education. (1998/629). Helsinki: Ministry of Justice. Available [Online]: http://www.finlex.fi/fi/laki/smur/1998/19980629

Leskisenoja, E., \& Uusiautti, S. (2015). PERMA-based teaching methods as the way to enhance well-being and engagement in students. Presented in New Ways to Teach and Learn for Student Engagement, Stanford University, Palo Alto, CA, USA, 21 April 2015.

Lévi-Strauss, C. (1966). The savage mind. Chicago, IL: University of Chicago Press.

Lieblich, A., Tuval-Mashiach, R., \& Zilber, T. (1998). Narrative research: Reading, analysis, 
and interpretation. London, England: Sage.

Liesveld, R., Miller, J. A., \& Robinson, J. (2005). Teach with your strengths. How great teachers inspire their students. New York, NY: Gallup Press.

Linkins, M., Niemiec, R. M., Gillham, J., \& Mayerson, D. (2014). Through the lens of strength: A framework for educating the heart. The Journal of Positive Psychology, 10(1), 64-68. http://dx.doi.org/10.1080/17439760.2014.888581

Linley, A., Willars, J., \& Biswas-Diener, R. (2010). The strengths book: Be confident, be successful, and enjoy better relationships by realising the best of you. Coventry: CAPP Press.

Lopez, S. J., \& Louis, M. C. (2009). The principles of strengths-based education. Journal of College \& Character, 10(4), 1-8. http://dx.doi.org/10.2202/1940-1639.1041

Määttä, K., \& Uusiautti, S. (2012a). How to enhance the smoothness of university students' study paths? International Journal of Research Studies in Education, 1(1), 47-60. http://dx.doi.org/10.5861/ijrse.2012.v1i1.16

Määttä, K., \& Uusiautti, S. (2012b). Pedagogical authority and pedagogical love - connected or incompatible? International Journal of Whole Schooling, 8(1), 21-39.

Magnusson, D., \& Mahoney, J. L. (2003). A holistic person approach for research on positive development. In L. G. Aspinwall \& U. M. Staudinger (Eds.), A psychology of human strengths: Fundamental questions and future directions for a positive psychology (pp. 227-244). Washington, DC: American Psychological Association.

Matriculation Examination Board. (2012). Ylioppilastutkinto 2011. Tilastoja ylioppilastutkinnosta [Matriculation Examination 2011. Information about Matriculation Examination]. Helsinki: Matriculation Examination Board.

McAdams, D. P. (2012). Exploring psychological themes through life-narrative accounts. In J. A. Holstein \& J. F. Gubrium (Eds.), Varieties of narrative analysis (pp. 15-32). London: Sage.

Noddings, N. (2005). The challenge to care in schools. An alternative approach to education. (2nd ed.) New York, NY: Teachers College Press.

Norberg-Schonfeldt, M. (2008). Children's school achievement and parental work: An analysis for Sweden. Education Economics, 16(1), 1-17. http://dx.doi.org/10.1080/09645290701273525

O'Connell, D. (2006). Brief literature review on strength-based teaching and counselling. Ontario: Research and draft prepared for the Metropolitan Action Committee on Violence Against Women and Children (METRAC). Retrieved from http://www.strengthsineducation.ca/uploads/2/2/0/0/22003628/strength.based.learning.lit .review.pdf

Organisation for Economic Cooperation and Development. (2014). PISA 2012 Results in 
Focus: What 15-year-olds know and what they can do with what they know. Paris: OECD. Retrieved from http://www.oecd.org/pisa/keyfindings/pisa-2012-results-overview.pdf

Peavy, R. V. (1996). Counselling as a culture of healing. British Journal of Guidance and Counselling, 24(1), 141-150. http://dx.doi.org/10.1080/03069889608253714

Peavy, R. V. (2000). Sociodynamic perspective and the practice of counselling. Presented in the Annual Conference of the National Consultation on Career Development, Ottawa, Ontario, 24-26 January 2000.

Peavy, R. V., \& Li, H. Z. (2003). Social and cultural context of intercultural counselling. Canadian Journal of Counselling, 37(3), 186-196.

Peterson, J., Duncan, N., \& Canady, K. (2009). A longitudinal study of negative life events, stress, and school experiences of gifted youth. Gifted Child Quarterly, 53, 34-49. http://dx.doi.org/10.1177/0016986208326553

Polkinghorne, D. E. (1988). Narrative knowing and the human sciences. Albany, NY: Statue University of New York Press.

Polkinghorne, D. E. (1995). Narrative configuration in qualitative analysis. In J. A. Hatch \& R. Wisniewski (Eds.), Life history and narrative (pp. 5-23). London: Falmer.

Pulkka, A.-T., \& Niemivirta, M. (2013). Adult students' achievement goal orientations and evaluations of the learning environment: a personcentred longitudinal analysis. Educational Research and Evaluation, 19(4), 297-322. http://dx.doi.org/10.1080/13803611.2013.767741

Quinlan, D., Swain, N., \& Vella-Brodrick, D. A. (2012). Character strengths interventions: Building on what we know for improved outcomes. Journal of Happiness Studies, 13, 1145-1163. http://dx.doi.org/10.1007/s10902-011-9311-5

Rath, T. (2007). StrengthsFinder 2.0. New York, NY: Gallup Press.

Riessman, C. K. (2008). Narrative methods for the human sciences. London: Sage.

Sahlberg, P. (2014). Uusi utelias koulu [New curious school]. In The Union of Upper Secondary School Students in Finland (Ed.), Edutopia 2050. Kirjoituksia koulutuksen tulevaisuudesta [Edutopia 2050. Writings about the future of education] (pp. 11-22). Helsinki: The Union of Upper Secondary School Students in Finland.

Salmela, M., \& Määttä, K. (2015). Even the best have difficulties: A study of Finnish straight-A graduates' resource-oriented solutions. Gifted Child Quarterly, 59(2), 124-135. http://dx.doi.org/10.1177/0016986214568720

Salmela, M., \& Uusiautti, S. (2013). Finnish straight-A graduates' perceptions of the smoothness of their study paths. Journal of Studies in Education, 3(4), 21-41. http://dx.doi.org/10.5296/jse.v3i4.4270 
Salmela, M., \& Uusiautti, S. (2015). A positive psychological viewpoint for success at school-10 characteristic strengths of the Finnish high-achieving students. High Ability Studies, iFirst. http://dx.doi.org/10.1080/13598139.2015.1019607

San Antonio, D. M. (2008). Understanding students' strengths and struggles. Educational Leadership, 65(7), 74-79.

Seligman, M. E. P. (2011). Flourish. A visionary new understanding of happiness and wellbeing. New York, NY: FreePress.

Seligman, M. E. P., Ernst, R. M., Gillham, J., Reivich, K., \& Linkins, M. (2009). Positive education: Positive psychology and classroom interventions. Oxford Review of Education 35(3), 293-311. http://dx.doi.org/10.1080/03054980902934563

Shearman, S. (2003). What is the reality of 'inclusion' for children with emotional and behavioural difficulties in the primary classroom? Emotional and Behavioural Difficulties, 8(1), 53-76. http://dx.doi.org/10.1080/13632750300507006

Välijärvi, J. (2014). Osaaminen kestävällä perustalla. Suomen PISA-tulosten kehitys vuosina 2000-2009. Tilannekatsaus helmikuu 2014 [Expertise on a secure basis. The development of Finland's PISA results in 2000-2009. A snapshot on February 2014]. Helsinki: National Board of Education.

van Manen, M. (2002). The tone of teaching. The language of pedagogy. (2nd ed.) London: The Althouse Press.

Viskari, S. (2003). Pedagogisen rakkauden mahdollisuus [The possibility of pedagogical love]. In M. Vuorikoski, S. Törmä, \& S. Viskari (Eds.), Opettajan vaiettu valta [The unspoken power of teachers] (pp. 155-177). Tampere: Vastapaino.

Warburton, E. C., Bugarin, R., \& Nuñez, A.-M. (2001). Bridging the gap: Academic preparation and postsecondary success of first-generation students. Education Statistics Quarterly, 3(3), 73-77.

Waters, L. (2011). A review of school-based positive psychology interventions. The Australian Educational and Developmental Psychologist, 28(2), 75-90. http://dx.doi.org/10.1375/aedp.28.2.75

Wood, A. M., Linley, P. A., Maltby, J., Kashdan, T. B., \& Hurling, R. (2011). Using personal and psychological strengths leads to increases in well-being over time: A longitudinal study and the development of the strengths use questionnaire. Personality and Individual Differences, 50, 15-19. http://dx.doi.org/10.1016/j.paid.2010.08.004

Yeager, J. M., Fisher, S. W., \& Shearon, D. N. (2011). Smart strengths. A parent-teacher-coach guide to building character, resilience, and relationships in youth. New York, NY: Kravis Publishing.

Zhao, C.-M., \& Kuh, G. D. (2004). Adding value: Learning communities and student engagement. Research in Higher Education, 45(2), 115-138. 
http://dx.doi.org/10.1023/B:RIHE.0000015692.88534.de

\section{Copyright Disclaimer}

Copyright for this article is retained by the author(s), with first publication rights granted to the journal.

This is an open-access article distributed under the terms and conditions of the Creative Commons Attribution license (http://creativecommons.org/licenses/by/3.0/). 